\title{
Use of Library Catalogue in Nigerian University Libraries: A Focus on Redeemer's University Library
}

\author{
Adeniran Pauline Oghenekaro \\ Tekena Tamuno Library, Redeemer's University, Ede, Nigeria \\ Email: omedop2006@yahoo.com
}

How to cite this paper: Oghenekaro, A.P. (2018) Use of Library Catalogue in Nigerian University Libraries: A Focus on Redeemer's University Library. Open Access Library Journal, 5: e4532.

https://doi.org/10.4236/oalib.1104532

Received: March 20, 2018

Accepted: May 18, 2018

Published: May 21, 2018

Copyright (c) 2018 by author and Open Access Library Inc.

This work is licensed under the Creative Commons Attribution International License (CC BY 4.0).

http://creativecommons.org/licenses/by/4.0/

\section{cC) (i) Open Access}

\begin{abstract}
The library as a service oriented organization is expected to provide the bibliographic resources and services channeled towards the fulfillment of its parent institution's goals and objectives. The library ensures that the resources so provided are well organized to allow easy access by the library users. The library users are expected to access the library resources with ease and use same maximally while at university. This paper examines the use of library catalogue in Nigerian university libraries with special emphasis on the Redeemer's University library, Osun State, Nigeria. Two hundred and fifty-one (251) students who used the library during the period of the study formed the sample for the study. A questionnaire was used as a data collection instrument for the study. The study revealed that a majority of the students do not use the library catalogue even though they are aware of the existence of the library catalogue. The researcher recommended therefore that a periodic user education programme be organized for the students to enable them to acquire the necessary skills of using the catalogue.
\end{abstract}

\section{Subject Areas}

Information Science, Library, Intelligence and Philology

\section{Keywords}

Library Catalogue, Catalogue Use, Information Seeking, Information Retrieval, Information Use, Library Use, University Libraries, Redeemer's University

\section{Introduction}

The library as being defined is an institution that acquires, organizes, preserves 
and makes available the recorded knowledge of man to the users. It can as well be seen as a collection of books and non book materials kept for reading and consultation. The missions of the library parent institution give an idea of the purpose for which that institution exists. The library plays an important role in the fulfillment of these missions. To play this role adequately, the library must be focused. The library as a service oriented organization must provide the bibliographic resources and services channeled towards the fulfillment of its parent institution's goals and objectives. The library ensures that the resources so acquired are well organized to allow easy access by the library users.

As important as a library is, if its resources are not properly organized, users will have difficulties in locating and retrieving materials. When users cannot locate needed materials, they feel frustrated. The study is aimed at finding out the extent to which the undergraduate students of Redeemer's University use its library catalogue when searching for materials in the library. The study also seeks to find out what problem students encounter when they use the catalogue. The findings of the study will help the Redeemer's university library and other libraries to improve on their services to users.

\section{Objectives of the Study}

The following objectives are set for this study:

1) To determine the undergraduate students' level of awareness of the library catalogue.

2) To ascertain the extent of use of the catalogue by undergraduate students to locate and retrieve books in the Redeemers University Library.

3) To identify the purpose for which undergraduate students use the catalogue.

4) To determine the method employ by undergraduate students in searching the catalogue.

5) To identify the constraints associated with the use of the library catalogue.

\section{Literature Review}

The library resources are organized to allow for easy access to the materials. The library plays the role of organizing the information resources and services in a way to ensure that user' needs are easily met. Cataloguing and classification are fundamental processes engaged in organizing information in libraries. The process of cataloguing is undertaken to describe materials so they can be identified, while classification on the other hand, entails the assignment of a call number that places library materials in order by subject. As described by [1], classification is a necessary device for organizing library resources. It leads the users to a specific subject, and groups books on the same or related subjects. According to the New Encyclopaedia Britannica, as cited by [2] classification is an arrangement adopted by libraries to facilitate its clientele to find documents quickly and easily.

A library catalogue is an inventory of all information resources (print and 
electronic) owned by a library. A library catalogue tells you what material is held by that library. Most libraries have computerized catalogues which allow you to access the library catalogue via the Internet. This type of computerized catalogue is often referred to as an OPAC (Online Public Access Catalogue) or Web OPAC. To access a library catalogue via the Internet you will need to know its URL, or web address. A library catalogue has information about everything the library owns. It is a database, and has a record (information like title, author, call number and library location).

A library catalogue serves the purpose of displaying library resources usually with descriptive comments and illustration. List, cited by [3] described a library catalogue as a file of records of a library's collection. The catalogue is an essential tool for both library users and library staff. It gives a comprehensive record of materials owned by the library, showing what the library has on a certain author, on a given subject, and with a certain title, and enabling library materials to be located easily [4]. A library catalogue provides multiple access points to the library's collection to aid learning and knowledge acquisition.

The library catalogue is an important tool. It is an index or a key to a library collection, containing an entry representing each item. Lending credence to this, [5] noted that the catalogue tells where in the library a book is placed. A library catalogue is a register of all items found in a library or group of libraries, such as a network of libraries at several locations. Similarly, [6] defined a catalogue as a record or list of books, periodicals, journals, pamphlets, monographs, audio-visual aids and other materials of a particular library, or a group of libraries or a private collection containing specified items of bibliographical information, namely author, title, edition, imprint, collation, etc. A bibliographic item can be any considered library material or linked from the catalog (e.g., a webpage) as far as it is relevant to the catalogue and to the users of the library.

If a user lacks skills to use a library catalogue, he or she may not be able to make effective use of the library resources. The studies of [7] found that users exhibit patterns of library catalogue usage, that education, experience and sophistication of library users determine the pattern or level of library catalogue use. Hence, [8] emphasized that the success or failure of students to locate resources in the library depends on the skill acquired though the library instruction progamme. [9] confirmed that the methods applied in teaching contribute significantly to whether a student will perform well in a subject or not. [10] had shown light on bibliographic elements of library catalogue for its effective utilization. There is need to teach users the importance of every element on the library catalogue for proper understanding of same. This is important because, in spite of the benefits which students can derive from catalogue use, its use is still poor in Nigerian university libraries. [11] found that catalogue use in Latunde Odeku Medical Library was poor. The author attributed the reason for the poor usage to lack of user education programme. In the same vein, the study of [12] found that a majority of the users preferred going directly to the shelves to 
search for materials rather than going through the catalogue cabinet. It was concluded that the respondents found the use of the library catalogue as a waste of time.

\section{Methodology}

This study was conducted at Redeemer's University Library, Osun State, Nigeria. The study employed descriptive research, using a questionnaire as instrument for collecting data on the use of library catalogue among undergraduate students. The questionnaire was divided into six sections. The sections collected information on the demographic variables of the respondents, level of awareness of availability of library catalogue, extent of use of catalogue, purpose of use of catalogue, methods of use and constraints associated with catalogue use respectively. A total of 300 questionnaires were distributed randomly to the respondents within the university campus, of which 251 were returned and found valid for analysis. Simple percentages were used.

\section{Findings}

Table 1 revealed the ages of the respondents. Out of the 251 (100\%) respondents $160(63.7 \%))$ fell between ages 15 and 20 while $82(32.7 \%)$ were between ages 21 to 25 . This indicates that a majority of the students who took part in the survey were between ages 15 and 20 .

Table 2 showed the distribution of the respondents by gender. A total of one hundred and forty-nine (149) of the respondents were female while the remaining one hundred and two (102) were male. This reveals that a majority of the participants were female.

Table 3 demonstrated that out of the 251 (100\%) respondents, 83 (33.1\%) were 300 level undergraduates, 74 (29.5\%) were in 400 level, 54 (21.5\%) were 100 level undergraduates while $40(15.9 \%)$ were 200 level students. This indicates that a majority of the respondents were 300 level students.

Table 4 revealed the colleges of participants. One hundred and seventy-two (172) respondents were from the college of Management sciences, fifty-one (51) from the college of Natural Sciences while twenty-five (25) were from the College of Humanities. As shown above, a majority of those who participated in the survey were from the college of Management Sciences. This is owned to the fact that the college of Management Sciences has a larger population than the other colleges because it has more programmes. The college of Humanities has the least population of students.

Table 5 dealt with awareness of library catalogue. When the respondents were asked of their awareness of the existence of the library catalogue, 225 (89.6\%) of them indicated that they were aware of the existence of the library catalogue. 26 $(10.4 \%)$ of them said they were not aware of the existence of the library catalogue. This shows that a majority of the respondents were aware of the availability of a library catalogue. 
Table 1. Distribution by age.

\begin{tabular}{cccc}
\hline & Age & Frequency & Percent \\
\hline & $15-20$ & 160 & 63.7 \\
$21-25$ & 82 & 32.7 \\
& $26-30$ & 6 & 2.4 \\
& Total & 248 & 98.8 \\
& response & 3 & 1.2 \\
& Total & 251 & 100.0 \\
\hline
\end{tabular}

Table 2. Distribution by gender.

\begin{tabular}{ccc}
\hline Gender & Frequency & Percent \\
\hline Male & 102 & 40.6 \\
Female & 149 & 59.4 \\
Total & 251 & 100.0 \\
\hline
\end{tabular}

Table 3. Distribution by level of study.

\begin{tabular}{ccc}
\hline Level & Frequency & Percent \\
\hline 100 & 54 & 21.5 \\
200 & 40 & 15.9 \\
300 & 83 & 33.1 \\
400 & 74 & 29.5 \\
Total & 251 & 100.0 \\
\hline
\end{tabular}

Table 4. Distribution by college.

\begin{tabular}{ccc}
\hline College & Frequency & Percent \\
\hline Humanities & 25 & 10.0 \\
Management Sciences & 172 & 68.5 \\
Natural Sciences & 51 & 20.3 \\
No response & 3 & 12 \\
Total & 251 & 100.0 \\
\hline
\end{tabular}

Table 5. Awareness of the library catalogue.

\begin{tabular}{ccc}
\hline Response & Frequency & Percent \\
\hline Yes & 225 & 89.6 \\
No & 26 & 10.4 \\
Total & 251 & 100.0 \\
\hline
\end{tabular}

Table 6 indicated that a majority of the respondents never used the library catalogue when searching for materials in the library. 10 (4.0\%) of the respondents used the catalogue 5 or more times per week, 24 (9.6\%) of them used it 
twice a month, $31(12.4 \%)$ of them used it less than 6 times per year, $37(14.7 \%)$ used it once a month and 70 (27.9\%) of them never used it. This shows that only few students used the catalogue while the rest preferred browsing the shelves by themselves.

Table 7 revealed the respondents' purpose of use of library catalogue. When the respondents were asked to indicate the purpose for which they use the library catalogue, 94 (37.5\%) of them said they used it for research purpose, 66 (26.3) used it for enquiry while others used it for bibliographic record supply, document delivery and others. It could be concluded that a majority of the respondents used the library for research.

Table 8 showed the methods through which students search for information on the library catalogue. When the respondents were asked to indicate the search method they apply when searching the catalogue for materials, a majority of them said they searched by title. $82(32.7 \%)$ of them affirmed they searched by title, $46(18.3 \%)$ of them searched by subject, $22(8.8 \%)$ of them by author, 21 $(8.4 \%)$ of the respondents searched by keywords while $80(31.9 \%)$ of them did not indicate which search method they applied. This shows that more than half of the students search the catalogue using the title as search parameter.

Table 9 revealed the respondents' comments on their use of the library catalogue. $112(44.6 \%)$ of the participants indicated that they had always found what they searched for on the catalogue. 56 (22.3\%) responded in the negative. This implies that a majority of them had always found what they searched for on the catalogue.

Table 10 focused on the challenges associated with catalogue use. When the respondents were asked if they feel lost when searching for information on the catalogue, 94 (37.5\%) of them disagreed, 43 (17.1\%) responded in the affirmative while 114 (45.4\%) did not respond to the question. This indicates that more than half of the participants had difficulties using the Library catalogue.

Table 11 demonstrated that a majority of the respondents disagreed to the question that sought to know if lack of skills in the use of library catalogue was a constraint to their use of the catalogue. $114(45.4 \%)$ of the respondents disagreed, 29 (11.6\%) agreed that lack of skills required for the use of a library catalogue was a problem to them while 108 (43.0\%) of them did not respond to the question. From this, one could easily say that a majority of the students do not like to use the library catalogue when looking for books.

Table 6. Extent of use of catalogue.

\begin{tabular}{ccc}
\hline Response & Frequency & Percent \\
\hline 5 or more times per week & 10 & 4.0 \\
2 to 4 times per week & 45 & 17.9 \\
2 times per month & 24 & 9.6 \\
Once per month & 37 & 14.7 \\
Less than 6 times per year & 31 & 12.4
\end{tabular}




\section{Continued}

\begin{tabular}{ccc}
\hline Never & 70 & 27.9 \\
Total & 217 & 86.5 \\
No response & 34 & 13.5 \\
Total & 251 & 100.0 \\
\hline
\end{tabular}

Table 7. Purpose for the use of library catalogue.

\begin{tabular}{ccc}
\hline Response & Frequency & Percent \\
\hline Enquiry work & 66 & 26.3 \\
Bibliographic record supply & 9 & 3.6 \\
Document delivery & 5 & 2.0 \\
Research & 94 & 37.5 \\
Total & 174 & 69.3 \\
No response & 77 & 30.7 \\
Total & 251 & 100.0 \\
\hline
\end{tabular}

Table 8. Search Method use when searching for information.

\begin{tabular}{ccc}
\hline Search Method & Frequency & Percent \\
\hline Title & 82 & 32.7 \\
Author & 22 & 8.8 \\
Subject & 46 & 18.3 \\
Keyword & 21 & 8.4 \\
Total & 171 & 68.1 \\
No response & 80 & 31.9 \\
Total & 251 & 100.0 \\
\hline
\end{tabular}

Table 9. Do you always find what you search for on the catalogue?

\begin{tabular}{ccc}
\hline Response & Frequency & Percentage \\
\hline Yes & 112 & 44.6 \\
No & 56 & 22.3 \\
No Response & 80 & 31.9 \\
Total & 251 & 100 \\
\hline
\end{tabular}

Table 10. When I look for information, I feel completely lost (Constraint).

\begin{tabular}{ccc}
\hline Response & Frequency & Percent \\
\hline Agreed & 22 & 8.8 \\
Strongly Agreed & 21 & 8.4 \\
Undecided & 114 & 45.4 \\
Disagreed & 60 & 23.9 \\
Strongly Disagreed & 34 & 13.5 \\
Total & 251 & 100.0
\end{tabular}


Table 11. I do not have the skills required to use the catalogue (Constraint).

\begin{tabular}{ccc}
\hline Response & Frequency & Percent \\
\hline Agreed & 20 & 8.0 \\
Strongly Agreed & 9 & 3.6 \\
Undecided & 108 & 43.0 \\
Disagreed & 58 & 23.1 \\
Strongly Disagreed & 56 & 22.3 \\
Total & 251 & 100.0 \\
\hline
\end{tabular}

\section{Discussion}

A library catalogue like an index tells the library user exactly where materials meeting his/her specific needs can be found. The better the access, the more use the library collection receives, and the more satisfied the user is in his or her search for information in the library. The findings of this study however revealed that the rate at which the respondents used the library catalogue was very low. Several factors could be responsible for the low frequency of use of the catalogue by the participants. [11] quoting Ozomo whose study found low usage of the library catalogue, attributed the low frequency of use to lack of user education programmes. Lack of skills could also discourage users from using the catalogue. Though a large number of the respondents of this study did not respond to the question that sought to elicit information on the challenges faced when using the catalogue, it could be concluded that the participants shied away from using the catalogue due to lack of the required skills and knowledge. Some of the respondents preferred browsing the shelves without first consulting the library catalogue as revealed in the findings. This corroborates the study of Islam [13]. Observations from the findings indicate the needs for quality user education/instructions, training on skills acquisition, etc. [14] pointed out that for effective use of library catalogue and its services, awareness programme must be incorporated into the library, which include, book display programme, orientation programme, information brochures, user education and library instruction. This will enable the students gain the necessary skills required for using the catalogue. Also regular orientation programmes will help to arouse their interest in the use of the catalogue. In the light of this, the researcher gave the following recommendations.

\section{Recommendations}

The researcher recommended the followings for improvement in the use of catalogue in Redeemer's University library based on the findings of the study.

- The library management should organize a periodic user education programme for the undergraduate students. This will enable them gain the needed skills to use the library catalogue maximally when searching for books and other information resources. 
- Guidelines for the use of the library catalogue should be prepared by the library authorities and paced in conspicuous points for the users to see.

- Regular orientation programme should be organized for the undergraduate students.

- The library management should organize demonstration on the use of the catalogue at the beginning of every semester to inculcate the culture of using the catalogue in students.

\section{Conclusion}

A library catalogue contained information providing many access points needed by library users looking for information in the library. The use of the catalogue makes information search easier and adequate. Periodic user education programme and training by library workers should be organized for the undergraduate students so that they can acquire the required skills to use the catalogue. This will increase the usage of the library as users will retrieve books and other information resources with ease. To better study this topic in the future, the researcher would like to suggest that a public or a combination of public and private institutions be considered as a research focus for a more general conclusion.

\section{References}

[1] Opaleke, J.S., Olayemi, T.K. and Aina, R. (2006) School Library Management for Teacher Librarian. Nathadex Publishers, Ilorin.

[2] Ramesh, P. and Shivendra, S. (2012) The Need and Importance of Library Classification in the ICT Era. Journal of Indian Library Association, 48, 25-30.

[3] Ojedokun, A.A. (2007) Information Literacy for Tertiary Education Students in Africa. Third World Information Services Limited, Ibadan.

[4] Posigha, B.E. (2010) The Use of the Library Catalogue by Undergraduate Students in Niger Delta University Library. Library Philosophy and Practice. https://digitalcommons.unl.edu/libphilprac/

[5] Apotiade, J.K. (2002) Ibadan Distance Learning Centre Series: LSE 302 Cataloguing and Classification. Distance Learning Centre University of Ibadan, Ibadan, p. 5.

[6] Atanda, L.A. and Ugwulebo, J.E. (2017) Awareness, Access and Utilization of Library Catalogue by Undergraduate Students of the College of Law, Osun State University Osogbo, Osun State, Nigeria. International Journal of Library and Information Science, 9, 115-121.

[7] Ojo-Ade, C.O. and Jagboro, K.O. (2000) Subject Catagloue Use at the Hezekiah Oluwasanmi Library, Obafemi Awolowo University. African Journal of Library Archives and Information Science, 10, 177-186.

[8] Amkpa, S.A. and Iman, A.I. (2011) Library Instruction Programme as a Correlate of Student Catalogue Use in Colleges of Education Libraries. Library Philosophy and Practice (e-journal) 456. http://digitalcommons.unl.edu/libphilprac/456

[9] Fatiloro, O.F. (2005) Effective Teaching of Language and Communication Skills in a Democratic Era Topics in General Studies. Library Philosophy and Practice, 1, 148-152.

[10] Aina, L.O. (2004) Library and Information Science Text for Africa. Thrid World 
Information Services, Ibadan, 110-122.

[11] Okorafor, C.N. (2006) Using Library Catalogue as Access to Academic Library Collection in Nigeria. Journal of the Nigerian Library Association, Imo State Chapter, 4, 37-43.

[12] Ishola, B.C. and Ojeniyi, Y.Z. (2015) Users Attitude towards the Use of Library Catalogue in two Selected University Libraries in South West Nigeria. Journal of Applied Information Science and Technology, 8, 44-54.

[13] Islam, M.M. (2010) The Use of the Library Catalogue by Undergraduates. Library Philosophy and Practice.

[14] Umesh, K.Y. (2012) Best Practices Adopted in Academic Libraries and Information Resources Centre. International Journal of Information Dissemination and Technology, 2, 186-188. 